\title{
Increased Epicardial Adipose Tissue Thickness: A new Indicator of Subclinical Atherosclerosis in Non-Fat Children with Migraine
}

\author{
Artmış Epikardiyal Adipoz Doku Kalınlığı: Migrenli ve Obez Olmayan \\ Çocuklarda Yeni Bir Subklinik Ateroskleroz Göstergesi
}

\author{
Oyku TOSUN $\odot$, Elif KARATOPRAK $\odot$
}

Ethics Committee Approval: This study approved by the Istanbul Medeniyet University, Goztepe Training and Research Hospital Clinical Studies Ethic Committee, 26 October, 2017, 2017/0314. Conflict of interest: The authors declare that they have no conflict of interest. Funding: None.

Informed Consent: Informed consent was taken from all participants.
Cite as: Tosun Ö, Karatoprak E. Increased Epicardial Adipose Tissue Thickness: A new Indicator of Subclinical Atherosclerosis in Non-Fat Children with Migraine. Medeniyet Med J. 2019;34:160-5.

\begin{abstract}
Objective: Epicardial adipose tissue is an important predictive factor of incident cardiovascular events independent from the plasma concentration of circulating biomarkers as well as patient's traditional risk factors. In our study, we aimed to evaluate both epicardial adipose tisssue thickness and carotid intima-media thickness to detect the link between migraine and the increased risk of cardivascular events in children with migraine, independent from traditional risk factors like obesity, high serum lipid and conventional C- reactive protein levels.

Methods: Forty-five migraine patients and 47 age, and gender-matched healthy children were assesed. regarding carotid intima media and epicardial adipose tissue thickness parameters measured by echocardiography were compared between two groups.

Results: No significant difference was detected in children with migraine and control group in terms of serum lipid levels, C-reactive protein levels that are known to be related with coronary vascular changes between two groups. The statistically significant difference was found in carotid intima media and epicardial adipose tissue thickness values between the study and control groups $(p<0.001)$. A significantly positive correlation was found between carotid intima media and epicardial adipose tissue thickness values in migraine group.

Conclusion: Early vascular changes in carotid artery can be related to the proinflammatory and inflammatory properties of epicardial adipose tissue thickness in children with migraine. So, we can consider that independent from the traditional risk factors we can detect the increased risk of cardiovascular events in children with migraine attacks.
\end{abstract}

Keywords: Atherosclerosis, carotid intima-media, epicardial adipose tissue, migraine, pediatrics

öz

Amaç: Epikardiyal yağ dokusu, dolaşımdaki biyobelirteçlerin plazma konsantrasyonundan ve hastanın geleneksel risk faktörlerinden bağımsız olarak meydana gelen kardiyovasküler olayların önemli bir prediktif faktörüdür. Çalışmamızda, obezite, yüksek serum lipid ve konvansiyonel C-reaktif protein seviyeleri gibi geleneksel risk faktörlerinden bağımsız olarak, migren ile kardiyovasküler risk arasındaki bağlantı riskini saptamak için hem epikardiyal yağ dokusu kalınlığını hem de karotis intima media kalınlığını değerlendirmeyi amaçladık.

Yöntem: Kırk beş adet migren hastası, kırk yedi yaş ve cinsiyet olarak uyumlu sağlıklı çocuk değerlendirildi. Ekokardiyografi ile ölçülen karotis intima media ve epikardiyal yağ dokusu kalınlığı parametreleri iki grup arasında karșılaștırıldı.

Bulgular: Migren ve kontrol grubundaki çocuklar arasında koroner vasküler değişikliklerle ilişkili olduğu bilinen serum lipid düzeyleri, C-reaktif protein düzeyleri açısından anlamlı fark saptanmadı. Calışma grubu ile kontrol grubu karşılaștırıldığında karotis intima media ve epikardiyal yağ dokusu kalınlığı değerlerinde istatistiksel olarak anlamlı fark bulundu $(p<0,001)$. Migren grubunda karotis intima media ile epikardiyal yağ dokusu kalınlığı değerleri arasında istatistiksel olarak anlamlı bir ilișki bulundu.

Sonuç: Karotid arterdeki erken vasküler değişiklikler, migrenli çocuklarda epikardiyal yağ dokusu kalınlığının proinflamatuar ve enflamatuvar özellikleriyle ilișkili olabilir. Bu nedenle, migren atakIarı olan çocuklarda, geleneksel risk faktörlerinden bağımsız olarak, kardiyovasküler olay riskinin arttığını tespit edebileceğimizi düşünebiliriz.

Anahtar kelimeler: Ateroskleroz, karotis intima media, epikardiyal adipoz doku, migren, pediatri
Received: 13.01 .2019

Accepted: 25.02 .2019

Online First: 10.06 .2019

Corresponding Author: O. Tosun

ORCID: 0000-0003-1031-273X

Istanbul Medeniyet University Faculty of Medicine, Department of

Pediatrics, Division of Pediatric Cardiology, Istanbul - Turkey

isaltosun@hotmail.com

E. Karatoprak ORCID: 0000-0003-2515-1764 Istanbul Medeniyet University Faculty of Medicine,

Department of Pediatrics, Division of Pediatric Neurology, Istanbul, Turkey 


\section{INTRODUCTION}

Migraine is a common neurovascular disorder characterised with recurrent attacks between pain-free periods ${ }^{1}$. Cortical spreading depression, neuroinflammation and craniovascular contractile dysfunction have been implicated in its pathogenesis ${ }^{2}$. In addition, neuropeptides and cytokines play a role in the neuroinflammatory process and vascular changes ${ }^{3}$. Central and peripheral pathways regulating nutritional and adipose tissue function intensively overlap with pathways involved in the pathophysiology of migraine ${ }^{4}$. Similarly, specific proteins and peptides, such as serotonin, orexin, leptin, adiponection, are involved in both feeding and migraine mechanisms ${ }^{5}$. Several studies have investigated these mechanisms in migraine and obesity ${ }^{4-6}$. Some adult and pediatric studies have showed the link between migraine and vascular events such as ischemic stroke and atherosclerosis as well ${ }^{7,8}$.

Obesity has been associated with increased risk of cardiovascular disease ${ }^{9,10}$. The risk of cardiovascular event is not only related to the amount of the adipose tissue, but more importantly to its location. Epicardial adipose tissue thickness (EAT) is an important predictive factor for incident cardiovascular events because proinflammatory and inflammatory properties of epicardial adipose tissue that surrounds the heart is independent from the serum concentrations of circulating biomarkers as well as patient's traditional risk factors such as high lipid levels and obesity ${ }^{11-14}$. Echocardiography is a reproducible, low-cost, noninvasive, readily available, manual technique which can be used to measure epicardial adipose tissue thickness without ionizing radiation ${ }^{15}$.

Measurement of carotid intima-media thickness (CIMT) by echocardiography is an easy and operator-dependent manual technique. The methodology is reliable among physicians because it is reproducible ${ }^{16}$. Also, there are some studies which demonstrated presence of a strong corre- lation between early atherosclerotic changes detected by measurement of carotid intima-media thickness and cardiovascular risk factors ${ }^{17,18}$.

We aimed to evaluate both epicardial adipose tisssue thickness and carotid intima-media thickness to detect the link between migraine and the increased risk of cardivascular events in children with migraine, independent from traditional risk factors like obesity, high serum lipid and C-reactive protein levels.

\section{MATERIAL and METHODS}

\section{Study population}

Istanbul Medeniyet University, Goztepe Training and Research Hospital Clinical Studies Ethic Committee approved this prospective study on 26 October, 2017 with 2017/0314 report number. Informed consent was taken from all participants.

Ninety-two individuals who were referred to outpatient clinics of pediatric neurology and pediatric cardiology between November 2017 and January 2018 were included in the study. Forty-five children with migraine with or without auras according to The International Classification of Headache Disorders, $3^{\text {rd }}$ edition (beta version) (ICHD-3 beta) criteria in 2013 (patient group) and 47 healthy, age-, and body mass index-matched children (control group) were enrolled in the study ${ }^{19}$. Patients with a known history of cardiovascular disease, diabetes, hypertension, obesity, hyperlipidemia, metabolic disorders, significant blood chemistry abnormalities, smoking, congenital or acquired heart disease, renal failure, chronic inflamatory disease and those taking medical treatment (especially nonsteroidal anti-inflammatory agents) and poor echocardiographic images were excluded from the study. Participants of patient and conrol groups didn't receive any medication prior to evaluation. Children with migraine were assessed by the same neurologist and questioned about auras, frequency, and duration of attacks and age at onset of migraine. The same blinded pediatric 
cardiologist performed a detailed cardiac examination including electrocardiographic and echocardiographic evaluation in healthy controls and migraine patients after the diagnosis of migraine during attack-free period. Blood samples were taken after 12 hours of fasting from the children with migraine during attack- free period and from the healthy controls. Serum lipid, vitamin $B_{12}, 25-$ hidroxyvitamin D, C-reactive protein levels (CRP) and complete blood counts were assessed. Anthropometric measurements were performed in order to calculate body mass index.

\section{Echocardiography}

The subclinical vascular disease imaging protocol for evaluation of carotid artery intima-media thickness and detection of carotid plaques was performed according to the standardized protocol of American Society of Echocardiography ${ }^{20}$. Autonomic software for any measurements was not used in our study. CIMT and EAT measurements were performed with Samsung H60 Echocardiography Systems (Samsung Healtcare). Right carotid artery intima-media measurements were done using a linear 4-9 $\mathrm{MHz}$ transducer on M-mode while the patient was laid in supine position with his/her neck slightly rotated to to left side. We placed the probe along the vessel axis to obtain a longitudinal scan of common carotid arteries. Intima-media thickness was measured only at posterior wall and $1.5 \mathrm{~cm}$ proximal to the carotid artery bifurcation. Three heart cycle measurements of artery were done and the mean values of these measurements were recorded. The measurement of the right ventricular epicardial fat which is a hypoechoic space anterior to the ventricular wall was chosen because it was the highest absolute epicardial fat layer thickness. Epicardial adipose tissue thickness was measured with a linear 3.0- to $11 \mathrm{mHz}$ signal transducer on B-mode at end-diastole from both the parasternal long and short axis views using aortic annulus as an anatomic reference. The maximum values were measured and the mean value was reported.

\section{Statistical Analysis}

We used SPSS for Windows software package (Version 15.0, SPSS Inc. Chicago, IL, USA) to statistically analyze our data. We used Student's $t$ test to compare groups, chi-square test to compare qualitative variables and Pearson correlation test to determine the relationship between the variables. We considered $p$ values less than 0.05 as statistically significant.

\section{RESULTS}

Forty-five children with newly diagnosed untreated migraine (16 males, 29 females; mean age $147 \pm 36$ months; 70-204 months) (study group) and 47 healthy children (17 males, 30 females; mean age $138,86 \pm 43,37$ months; 67-205 months) (control group) were enrolled. In the study group, 6 patients were diagnosed as migraine with aura and 39 diagnosed as migraine without aura. A family history of migraine was reported in 30 patients. None of the patients in tht study and control groups reported family history of coronary vascular disease. The transthoracic echocardiography and 12-lead electrocardiographic, and neurological examination results were within normal limits in all children. None of the patients were receiving prophylactic treatment for migraine. No significant difference was detected in children with migraine and control group in terms of age, sex and body mass indices. Mean systolic and diastolic blood pressures of the study and control groups were in normal limits. Lipid (triglycerides, low-density lipoprotein, high-density lipoprotein, and cholesterol), vitamin $B_{12}$ and 25-hidroxyvitamin D levels, complete blood count, C-reactive protein levels that are known to be related with coronary vascular changes were in normal limits in the study and control groups. No significant difference was found in terms of the blood pressure, serum lipid, vitamin $\mathrm{B}_{12}$, C-reactive protein, 25-OH vitamin D levels, and platelet counts (Table 1).

The only statistically significant difference was found in carotid intima-media and epicardial adipo- 
se tissue measurements between the study and control groups $(p<0.001)$ (Table 2$)$.

Table 1. The clinical and labaratory characteristics of the patient and control groups.

\begin{tabular}{|c|c|c|c|}
\hline & $\begin{array}{l}\text { Control Group } \\
(n=47)\end{array}$ & $\begin{array}{l}\text { Study Group } \\
(n=45)\end{array}$ & $\mathbf{p}$ \\
\hline Sex (Male/Female) & $\begin{array}{ll}\text { Female } & 30 \\
\text { Male } & 17\end{array}$ & $\begin{array}{ll}\text { Female } & 29 \\
\text { Male } & 16\end{array}$ & 0.89 \\
\hline Age (month) & $138.86 \pm 43.37$ & $147 \pm 36$ & 0.28 \\
\hline BMI ${ }^{1}(\mathrm{~kg} / \mathrm{m})$ & $18.56 \pm 2.11$ & $18.79 \pm 2.64$ & 0.652 \\
\hline $\begin{array}{l}\text { Systolic blood } \\
\text { pressure (mmHg) }\end{array}$ & $110.4 \pm 3.04$ & $108.3 \pm 2.8$ & 0.45 \\
\hline $\begin{array}{l}\text { Diastolic blood } \\
\text { pressure }(\mathrm{mmHg})\end{array}$ & $58.2 \pm 7.1$ & $59.4 \pm 6.4$ & 0.48 \\
\hline Cholesterol (mg/dl) & $13.38 \pm 10.32$ & $134.11 \pm 11.11$ & 0.19 \\
\hline $\begin{array}{l}\text { Low-density } \\
\text { lipoprotein (mg/dl) }\end{array}$ & $96.57 \pm 7.18$ & $95.27 \pm 6.52$ & 0.91 \\
\hline $\begin{array}{l}\text { High-density } \\
\text { lipoprotein }(\mathrm{mg} / \mathrm{dl})\end{array}$ & $51.23 \pm 2.41$ & $51.18 \pm 3.02$ & 0.42 \\
\hline Triglyceride (mg/dl) & $79.81 \pm 16.76$ & $51.33 \pm 2.73$ & 0.32 \\
\hline $\begin{array}{l}\text { Serum } C \text { reactive } \\
\text { protein }(\mathrm{mg} / \mathrm{dl})\end{array}$ & $0.03 \pm 0.01$ & $0.03 \pm 0.02$ & 0.96 \\
\hline Vitamin $B_{12}(p g / m l)$ & $400 \pm 9$ & $405 \pm 10$ & 0.82 \\
\hline $\begin{array}{l}\text { 25-hidroxyvitamin D } \\
\text { (ng/dl) }\end{array}$ & $35 \pm 3$ & $37 \pm 2$ & 0.73 \\
\hline Platelet count $\left(\mathrm{mm}^{3}\right)$ & $310 \pm 67$ & $308 \pm 62$ & 0.48 \\
\hline
\end{tabular}

Values are presented as mean \pm standart deviation, The mean difference is significant at the 0.05 level, ${ }^{1}$ Body mass index

Table 2. Comprasion of carotid intima media thickness and apicardial adipose tissue thickness.

\begin{tabular}{llll}
\hline & $\begin{array}{l}\text { Study Group } \\
(\mathbf{n = 4 7 )}\end{array}$ & $\begin{array}{l}\text { Control Group } \\
(\mathbf{n = 4 5})\end{array}$ & $\mathbf{p}$ \\
\hline $\mathrm{CIMT}^{1}(\mathrm{~mm})$ & $1.12 \pm 0.32$ & $0.48 \pm 0.15$ & $<0.001$ \\
$\mathrm{EAT}^{2}(\mathrm{~mm})$ & $6.32 \pm 0.71$ & $3.73 \pm 0.521$ & $<0.001$ \\
\hline
\end{tabular}

Values are presented as mean \pm standart deviation, the mean difference is significant at the 0.05 level, 'Carotid intima media thickness, ${ }^{2}$ Epicardial adipose tissue

In migraine group, we didn't find any correlation between carotid intima-media and epicardial adipose tissue thickness values and clinical and laboratuary parameters (Table 3). We didn't find any significant difference between the patients diagnosed as migraine with and without aura in terms of carotid intima-media and epicardial adipose tissue thickness values as well $(p=0.42)$.
Table 3. Correlation between carotid intima media thickness-epicardial adipose tissue and clinical and laboratuary parameters.

\begin{tabular}{llll}
\hline & & CIMT $^{\mathbf{1}}(\mathbf{m m})$ & EAT $^{\mathbf{2}}(\mathbf{m m})$ \\
\hline Age (months) & $\mathrm{r}^{*}$ & 0.17 & 0.14 \\
& $\mathrm{p}^{* *}$ & 0.26 & 0.35 \\
BMI $^{3}$ (kg/m) & $\mathrm{r}^{*}$ & 0.18 & 0.16 \\
& $\mathrm{p}^{* *}$ & 0.23 & 0.29 \\
Blood Pressure (mmHg) & $\mathrm{r}^{*}$ & 0.12 & 0.13 \\
& $\mathrm{p}^{* *}$ & 0.43 & 0.39 \\
Low-density lipoprotein & $\mathrm{r}^{*}$ & 0.16 & 0.14 \\
(mg/dl) & $\mathrm{p}^{* *}$ & 0.29 & 0.35 \\
& & & \\
High-density lipoprotein & $\mathrm{r}^{*}$ & 0.19 & 0.16 \\
(mg/dl) & $\mathrm{p}^{* *}$ & 0.21 & 0.29 \\
Triglyceride (mg/dl) & $\mathrm{r}^{*}$ & 0.18 & 0.18 \\
& $\mathrm{p}^{* *}$ & 0.23 & 0.23 \\
Cholesterol (mg/dl) & $\mathrm{r}^{*}$ & 0.17 & 0.19 \\
& $\mathrm{p}^{* *}$ & 0.26 & 0.21 \\
& & &
\end{tabular}

*Pearson correlation, ${ }^{* *}$ Correlation is significant at the level 0.01 , ${ }^{1}$ Carotid intima media thickness, ${ }^{2}$ Epicardial adipose tissue, ${ }^{3}$ Body mass index

The mean frequency of migraine attacks was $3.93 \pm 2.02$ per month. The mean age at the onset of migraine was recorded as $117.13 \pm 35.46$ months (range 65 to 192 months). (range 1 to 7 per month) and the mean duration of attacks was $2.44 \pm 1.17$ hours (range 1 to 4 hours).

In the patient group, no significant correlation was found between age at onset of migraine, frequency, and duration of attacks and carotid intimamedia thickness measurements $(r=0.008, p=0.95$; $r=0.014, p=0.92 ; r=0.22, p=0.14$, respectively). No significant correlation was found between age at onset of migraine, frequency, and duration of attacks and epicardial adipose tissue measurements $(r=0.05, p=0.73 ; r=0.033, p=0.82 ; r=0.17$, $\mathrm{p}=0.24$, respectively)

We found a significantly positive correlation between epicardial adipose tissue and carotid intimamedia thickness values in migraine group $(r=0.44$, $p=0.0024$ ). 


\section{DISCUSSION}

Central and peripheral patways regulating nutritional and adipose tissue function intensively overlap with pathways involved in the pathophysiology of migraine $^{4}$. Some studies have investigated the link between migraine and obesity ${ }^{4-6}$. In a systematic review showing the link between obesity and migraine in childhood, the researchers have suggested that inflammatory mediators, neurotransmitters, leptin play a role in both nutrition and migraine pathophysiology ${ }^{21}$. Also, there are studies which have showed that epicardial adipose tissue thickness is a valuable predictive factor for incident cardiovascular events. They have suggested that proinflammatory and inflammatory properties of epicardial adipose tissue thickness is independent from the concentration of circulating biomarkers as well as patient's traditional risk factors such as high lipid levels and obesity ${ }^{11-14}$. When we evaluated all these previous studies, we considered investigating the epicardial adipose tissue thickness values of the patients with migraine to evaluate the risk of incident cardiovascular events. Although, body mass indices of all our patients were in normal limits, independent from the traditional risk factors, epicardial adipose tissue thickness measurements were found to be significantly higher in our pediatric migraine patients showing the increased risk for cardiovascular events. To our knowledge, there is no study evaluating epicardial fat tissue thickness in pediatric patients with migraine.

Some studies with large populations of adults have reported that patients with migraine had no increased risk for atherosclerosis ${ }^{22}$. Similar with our study, in an adult study and in two pediatric studies, higher carotid intima-media thickness values have been found in patients with migraine, showing the increased risk for cardiovascular event $^{7,23,24}$. Hamed et al. have found significantly increased carotid intima- media thickness parameters in the migraine patients, but different from our study, patients in their study had traditional risk factors for cardiovascular events, such as obe- sity, elevated blood pressure, cigarette smoking, and high blood lipid levels ${ }^{7}$.

Besir et al. have suggested that early atherosclerosis may be due to cranial inflammatory arteriopathy, which will arise in response to frequent and longer attacks ${ }^{23}$. However, similar with Poyrazoğlu et al. ${ }^{8}$ we didn't find any correlation between duration, and frequency of attack and carotid intima- media thickness. Additionally, we didn't find any correlation between epicardial adipose tissue thickness and these parameters.

Poyrazoğlu et al. have reported significantly increased carotid intima-media thickness values in the migraine patients without aura ${ }^{8}$. Since, only six of our patients were diagnosed as migraine with aura, we could not find any significant difference in CIMT and EAT values between the migraine patients with and without aura.

In our study, while the statistical significant difference between body mass index and carotid intima- media thickness was not found in children with migraine, we found a significant positive correlation between epicardial adipose tissue thickness and carotid intima-media thickness values. We thought that this finding depends on the place where the fat tissue was accumulated rather than the amount of it. So, we suggested that it can be more useful to measure epicardial adipose tissue thickness which is a low-cost, manual technique rather than body mass index to assess the risk for cardiovascular events in children with migraine.

In a retrospective and an uncontrolled chart review study, Welch et al. ${ }^{25}$ found inreased C-reactive protein levels in patients with migraine attacks and have indicated that inflammation has a significant role on the pathophysiology of atherosclerosis in patients with migraine. Similar with Poyrazoğlu et al, we assessed our patients during migrainefree period and we did'nt detect any significant difference in the serum C-reactive protein levels between study and control groups ${ }^{8}$. 
According to our findings, we thought that, although the body mass index is within normal limits, early vascular changes in carotid artery can be related to the proinflammatory and inflammatory properties of epicardial adipose tissue thickness. So, we can consider that, independent from the traditional risk factors such as obesity, high C-reactive protein and lipid levels, we can detect the increased risk for cardiovascular events in children with migraine attacks. Carotid intimamedia thickness and epicardial adipose tissue thickness measurements that can be performed by echocardiography are easy and noninvasive techniques for the evaluation of these vascular changes even in the early period.

\section{CONCLUSION}

Since migraine is a life-long disease, it is important to monitor children with migraine attacks for carotid intima-media and epicardial adipose tissue thickness during the follow-up period to detect early atherosclerotic vascular changes. In this manner, we can advise our patients with migraine attacks to avoid habits that accelerate atherosclerotic vascular changes like smoking, excessive salt intake, sedentary life, and weight gain.

\section{REFERENCES}

1. Lipton RB, Bigal ME. Migraine: epidemiology, impact and risk factors for progression. Headache. 2005;45(Suppl 1):S3-S13. [CrossRef]

2. Goadsby PJ, Lipton RB, Ferrari MD. Migraine- current understanding and treatment. N Engl J Med. 2002;346:25770. [CrossRef]

3. Bolay $H$, Reuter $U$, Dunn AK, et al. Intrinsic brain activity triggers trigeminal meningeal afferents in migraine model. Nat Med. 2002;8:136-42. [CrossRef]

4. Peterlin BL, Rapoport AM, Kurth T. Migraine and obesity: epidemiology, mechanisms and implications. Headache. 2010;50:631-48. [CrossRef]

5. Bigal ME, Lipton RB, Holland PR, Goadsby PJ. Obesity, migraine and chronic migraine: possible mechanism of interaction. Neurology. 2007;68:1851-61. [CrossRef]

6. Markus TE, Toldo I. Obesity and Migraine in Childhood. Curr Pain Headache. 2018;3:22-42. [CrossRef]

7. Hamed SA, Hamed EA, Ezz Eldin AM, Mahmoud NM. Vascular risk factors, endothelial function, and carotid thickness in patients with migraine: relationship to atherosclerosis. J Stroke Cerebrovasc Dis. 2010;19:92-103. [CrossRef]

8. Poyrazoğlu GH, Vurdem EU, Arslan A. Evaluation of carotid intima-media thickness in children with migraine: a marker of subclinical atherosclerosis. Neurol Sci. 2016;37:1663-9. [CrossRef]

9. Justin R. Ryder, Donald R. Dengel, David R. Jacobs, et al. Realtions among adiposity and insülin resistance with flow mediated dilatation, carotid intima-media thickness and arteriel stifness in children. J Peds. 2015;5:1-7.

10. Calle EE, Thun MJ, Petrelli JM, et al. Body-mass index mortality in a prospective cohort of U.S. adults. N Engl J Med. 1999;341:1097-105. [CrossRef]

11. Gastaldelli A, Basta G. Ectopic fat and cardiovascular disease: What is the link? Nutr Metab Cardiovasc Dis. 2010;20:481-90. [CrossRef]

12. Alexopoulus N, Mc Lean DS, Janik M, et al. Epicardial Adipose Tissue and coronary artery plaque characteristics. Atherosclerosis. 2010;210:150-4. [CrossRef]

13. Ding J, Hsu FC, Harris TB, et al. Association of epicardial fat with incident coronary heart disease: the MultiEthnic Study of Atherosclerosis (MESA). Am J Clin Nutr. 2009;90:499-504. [CrossRef]

14. Cheng VY, Dey D, Tamarappoo B, et al. Pericardial fat burden on ECG-gated noncontrast CT in asymptomatic patients who subsequently experience adverse cardiovascular events, JACC Cardiovasc Imaging. 2010;3:352-60. [CrossRef]

15. Talman AH, Psaltis PJ, Cameron JD, et al. Epicardial adipose tissue: far more than a fat depot. Cardiovasc Diagn Ther. 2014;4:416-29.

16. Pignoli P, Tremoli E, Poli A, Oreste P, Paoletti R. Intimal plus medial thickness of arterial wall: a direct measurement with ultrasound imaging. Circulation. 1986;74:13991406. [CrossRef]

17. Simons PC, Algra A, Bots ML, et al. Common carotid intima-media thickness and arteriel stiffness: indicators of cardiovascular risk in high-risk patients. The SMART study. Circulation. 1999;100:951-7. [CrossRef]

18. Mackinnon AD, Jerrard- Dunne P, Sitzer M, et al. Rates and determinats of site-specific progression of carotid artery intima media thickness: the carotid atherosclerosis progression study. Stroke. 2004;35:2150-4. [CrossRef]

19. Headache Classification Committee of the International Headache Society (IHS). The International Classification of Headache Disorders, $3^{\text {rd }}$ edition (beta version) Cephalalgia. 33: 629-808. [CrossRef]

20. Stein JH, Korcarz CE, Hurst RT, et al. Use of carotid ultrasound to identify subclinical vascular disease and evaluate cardiovascular disease risk: A consensus statement from the American Society of Echocardiography Carotid Intima-Media Thickness Task Force endorsed by the Society for Vascular Medicine. J Am Soc Echocardiogr. 2008;21:93-111. [CrossRef]

21. Farello G, Ferrara P, Antenucci A, Basti C, et al. The link between obesity and migraine in childhood: a systematic review. Ital J Pediatr. 2017;43:27. [CrossRef]

22. Stam AH, Weller CM, Janssens AC et al. Migraine is not associated with enhanced atherosclerosis. Cephalalgia. 2013;33:228-35. [CrossRef]

23. Besir FH, Kocer A, Dikici S, et al. The evaluation of Atherosclerosis in Migraine Patients. Pain Pract. 2013;13:41-5. [CrossRef]

24. Parmeggiani L, Saladin M, Egger F, et al. A thicker initmamedia carotid wall was found in a cohort of children with recent onset migraine. Acta Paediatr. 2016;105:e577e581. [CrossRef]

25. Welch KM, Brandes AW, Salerno L, Brandes JL. C-reactive protein may be increased in migraine patients who present with complex clinical features. Headache. 2006;46:197-9. [CrossRef] 